\title{
Current Immunotherapeutic Approaches in Pancreatic Cancer
}

\author{
Shigeo Koido, ${ }^{1,2,3}$ Sadamu Homma, ${ }^{3}$ Akitaka Takahara, ${ }^{1}$ Yoshihisa Namiki, ${ }^{2}$ \\ Shintaro Tsukinaga, ${ }^{1}$ Jimi Mitobe, ${ }^{1}$ Shunichi Odahara, ${ }^{1}$ Toyokazu Yukawa, ${ }^{1}$ \\ Hiroshi Matsudaira, ${ }^{1}$ Keisuke Nagatsuma, ${ }^{1}$ Kan Uchiyama, ${ }^{1}$ Kenichi Satoh, ${ }^{1}$ Masaki Ito, ${ }^{3}$ \\ Hideo Komita, ${ }^{1}$ Hiroshi Arakawa, ${ }^{1}$ Toshifumi Ohkusa, ${ }^{1,2}$ Jianlin Gong, ${ }^{4}$ and Hisao Tajiri ${ }^{1}$ \\ ${ }^{1}$ Division of Gastroenterology and Hepatology, Department of Internal Medicine, The Jikei University School of Medicine, \\ Tokyo 105-8461, Japan \\ ${ }^{2}$ Institute of Clinical Medicine and Research, The Jikei University School of Medicine, Tokyo 105-8461, Japan \\ ${ }^{3}$ Department of Oncology, Institute of DNA Medicine, The Jikei University School of Medicine, Tokyo 105-8461, Japan \\ ${ }^{4}$ Department of Medicine, Boston University School of Medicine, Boston, MA 02118, USA \\ Correspondence should be addressed to Shigeo Koido, shigeo_koido@jikei.ac.jp
}

Received 19 May 2011; Accepted 26 June 2011

Academic Editor: Bernhard Fleischer

Copyright () 2011 Shigeo Koido et al. This is an open access article distributed under the Creative Commons Attribution License, which permits unrestricted use, distribution, and reproduction in any medium, provided the original work is properly cited.

Pancreatic cancer is a highly aggressive and notoriously difficult to treat. As the vast majority of patients are diagnosed at advanced stage of the disease, only a small population is curative by surgical resection. Although gemcitabine-based chemotherapy is typically offered as standard of care, most patients do not survive longer than 6 months. Thus, new therapeutic approaches are needed. Pancreatic cancer cells that develop gemcitabine resistance would still be suitable targets for immunotherapy. Therefore, one promising treatment approach may be immunotherapy that is designed to target pancreatic-cancer-associated antigens. In this paper, we detail recent work in immunotherapy and the advances in concept of combination therapy of immunotherapy and chemotherapy. We offer our perspective on how to increase the clinical efficacy of immunotherapies for pancreatic cancer.

\section{Pancreatic Cancer}

Pancreatic tumors usually display a ductal, an acinar, or an endocrine differentiation. The majority (approximately 95\%) of pancreatic tumors arise from the exocrine component of the pancreas, and of these the significantly most common is ductal adenocarcinoma [1]. Pancreatic adenocarcinoma that is the fifth leading cause of cancer death worldwide is a lethal disease with an overall 5-year survival of only $6 \%$ [1]. Moreover, for locally advanced cancer patients, the life expectancy is about 6-8 months [1]. No adequate therapy for pancreatic cancer has yet been found, and most of patients diagnosed annually die within a year of diagnosis. Despite recent improvements in diagnostic techniques, pancreatic cancer is diagnosed at an advanced stage in most patients. Therefore, surgical resection (pancreaticoduodenectomy) can be performed in only a small number of patients [2]. Even after resection, recurrence occurs in the majority of the patients, leading to a median survival of about 18 months after resection. Although adjuvant treatment with both chemotherapy and radiation therapy was investigated, which demonstrated improvements in diseasefree survival and overall survival rates [3], new therapeutic approaches are still needed.

\section{Cytotoxic Chemotherapeutic Agents}

Gemcitabine ( $2^{\prime} 2^{\prime}$-difluorodeoxycytidine) is a chemotherapeutic drug that has become the standard treatment for advanced disease after showing superiority over 5 -fluorouracil (5-FU), while chemoradiation plus systemic chemotherapy is also still widely used [4]. Therefore, gemcitabine was established as the standard first line treatment for patients with advanced disease. Gemcitabine is a nucleoside analogue that exerts its antitumor activity via multiple mechanisms of action. These include (1) incorporation of gemcitabine into replicating DNA, which inhibits DNA replication and 
cell growth, (2) masked DNA chain termination, and (3) several self-potentiation mechanisms that serve to increase intracellular levels of the active compound [5]. It thus halts DNA synthesis and is invisible to DNA repair systems, leading the cells into the apoptotic pathway. However, most patients treated with gemcitabine do not survive longer than 6 months, as the tumor cells are naturally resistant to current chemotherapy. Subsequent trials aimed at improving survival have combined gemcitabine with various cytotoxic (platinums, fluoropyrimidines, or topoisomerase inhibitors) [6-10], or biological agents (tipifarnib [11], marimastat [12], or cetuximab [13]). However, the addition of the cytotoxic agents to gemcitabine did not lead to a statistically significant improvement in overall survival (OS) in patients with advanced pancreatic cancer [14-17].

\section{Biological Agents}

Some therapies based on mechanisms that target specific biologic pathways of tumors have commonly been referred to as "targeted therapy." While traditional cytotoxic drugs also target specific cellular process, the newer generation of agents is set apart by their targeting of a pathway or molecular that derives the growth, speed, survival, or maintenance of tumor cells specially. There is a sound rationale for combining a human epidermal growth factor receptor type 1 (HER1/EGFR) inhibitor and gemcitabine in pancreatic cancer. Erlotinib (Taraceva, Genentech, South San Francisco) is a small molecule HER1/EGFR tyrosine kinase inhibitor. The human HER1/EGFR is overexpressed in many pancreatic tumors and is associated with more aggressive disease and poorer outcome $[18,19]$. Blocking HER1/EGFR tyrosine kinase signaling improves the anticancer effects of gemcitabine [20]. Indeed, the combination of gemcitabine plus erlotinib significantly improved OS compared with gemcitabine alone [17]. This combination therapy first provided proof of principle of targeting HER1/EGFR in pancreatic cancer and showed erlotinib-improved survival when used concurrently with gemcitabine. Therefore, the US Food and Drug Administration (FDA) recently approved erlotinib for use in the first-line setting of advanced pancreatic cancer in combination with gemcitabine. However, this survival benefit was small, and the combination therapy increased the cost; therefore, erlotinib has not yet been widely incorporated into standard treatment protocols. Another study evaluating EGFR as a target in pancreatic cancer, using the monoclonal antibody cetuximab, has been completed. In patients with advanced pancreas cancer, cetuximab did not improve the outcome compared with patients treated with gemcitabine alone [13]. Moreover, studies evaluating monoclonal antibodies to vascular endothelial growth factor (VEGF) and using combinations of targeted agents in patients with advanced pancreatic cancer are underway.

\section{Immunotherapy}

The aim of antitumor immunotherapy is to induce efficient cytotoxic $\mathrm{T}$ lymphocyte (CTL) responses against pancreatic cancer cell. Dendritic cells (DCs) are powerful antigen-presenting cells (APCs) that play a pivotal role in the initiation, programming, and regulation of tumor-specific immune responses $[21,22]$. DCs can process endogenously synthesized antigens or exogenous antigens into antigenic peptides, presented to the cell surface as MHC class I-peptide complexes, and recognized by the $\alpha \beta$ T cell receptor (TCR) in CD8+ T cells [23]. In contrast, exogenous antigens are captured and delivered to the compartments of the endosome/lysosome, where they are degraded to antigenic peptides by proteases and peptidases, which are complexed with MHC class II and recognized by the $\alpha \beta$ TCR in CD $4+\mathrm{T}$ cells [23-25]. The $\alpha \beta$ TCR in CD $8+$ CTL can recognize MHC class I-peptide complexes on cancer cells and destroy cancer cells through effector molecules such as granzyme B and perforin (Figure 1) [26, 27]. Upon TCR-mediated cell activation, naive $\mathrm{CD} 4+\mathrm{T}$ cells can differentiate into at least four major lineages, Th1, Th2, Th17, and regulatory $\mathrm{T}$ (Treg) cells all of which participate in different types of immune responses (Figure 2) [28]. The Th1 cells produce interferon (IFN)$\gamma$ along with proinflammatory cytokines, such as tumor necrosis factor (TNF)- $\alpha$ and TNF- $\beta$, to activate DCs, which can regulate the survival and persistence of CD8+ CTLs as memory cells $[24,29]$. Th2 cells secrete interleukin (IL)-4 and IL-10 [24, 29]. The Th2 response is often associated with the humoral, antibody-based antitumor response [30, 31]. Th17 cells secrete IL-17 and IL-22, eliciting tissue inflammation implicated in autoimmunity [32-34]. There are increasing evidences that cancer cells-derived soluble factors promote the induction of tolerance through the generation of CD4 $+\alpha$ chain of IL-2R (CD25) + forkhead box P3 (Foxp3)+ Treg subset, which is linked to compromised antitumor immune responses [35].

The field of cancer immunotherapy is currently in an active state of preclinical and clinical investigations. The development of new treatment modalities, including specific immunotherapy, is of great importance in the treatment of pancreatic cancer. In support of the immunotherapy approach are the findings that pancreatic cancer cells express TAAs such as Wilms' tumor gene 1 (WT1) (75\%) [36], mucin 1 (MUC1) (over 85\%) [37], human telomerase reverse transcriptase (hTERT) (88\%) [38], mutated K-RAS $(73 \%)$ [38, 39], survivin (77\%) [40], carcinoembryonic antigen (CEA) (over 90\%) [41], HER-2/neu (61.2\%) [42], or p53 (67\%) [43] as potential targets for immunotherapy. Immunotherapies aim to recruit and activate $\mathrm{T}$ cells that recognize TAAs-specific antigens. Moreover, pancreatic cancer cells themselves actively contribute to immune suppression through production of immune suppressive cytokines (e.g., TGF- $\beta$, IL-10, and IL- 6 ) and by expressing surface molecules that mediate immune suppression (e.g., vascular endothelial growth factor (VEGF), Fas ligand (Fas-L), programmed death-1 ligand (PD-L1) and indolamine-2, and 3-dioxygenase (IDO)) [44]. In addition, the environment in pancreatic cancer is consisted of not only cancer cells but also immune suppressive cells such as cancer-associated fibroblasts (CAFs), tolerogenic DCs, myeloid-derived suppressor cells (MDSCs), immunosuppressive tumor-associated macrophages (TAMs), and Treg cells [44] (Figure 3). As a result, 

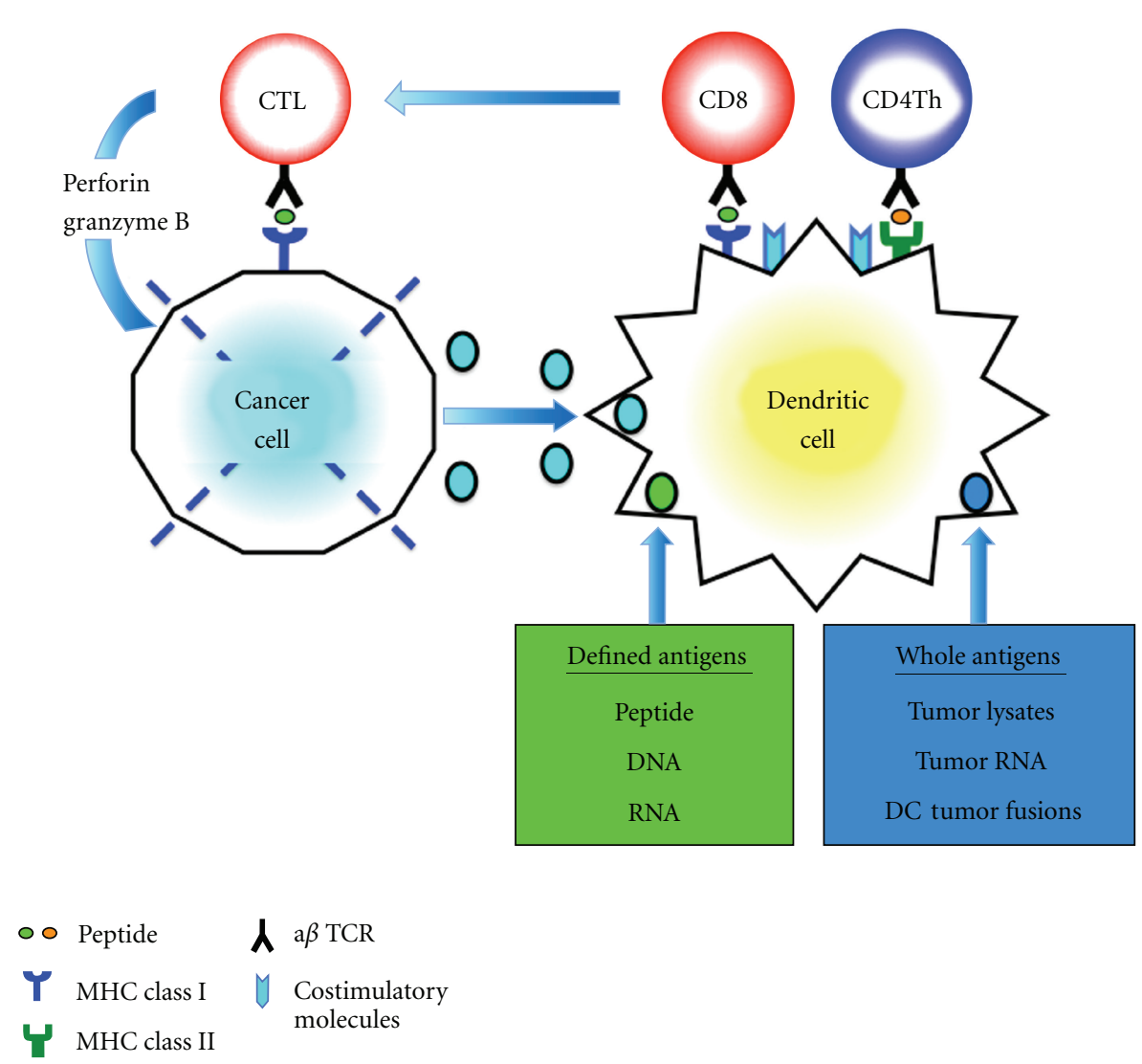

FIGURE 1: CTL induction by DCs. Antigens are taken up and degraded into peptide fragments by antigen-presenting cells, such as immature DCs. DCs process tumor-derived peptides and MHC class I peptides derived from DCs. They form MHC class I-peptide complexes, in the endoplasmic reticulum, which are transported to the surface of DCs and presented to CD8+ T cells. DCs also synthesize MHC class II peptides in the endoplasmic reticulum, which are transported to the cytoplasm where MHC class II-peptide complexes are assembled with tumor-derived peptides and presented to CD4+ T cells. The CD4+ T cells produce increased amounts of IL-2, which drives CD8+ T-cell proliferation. CD8+ T cells then become CTL, which can destroy cancer cells through effector molecules such as granzyme B and perforin.

immunosuppressive cells inhibit antitumor immunity by various mechanisms, including depletion of arginine and elaboration of reactive oxygen species (ROS) and nitrogen oxide (NO) [44]. Finally, an immunosuppressive tumor microenvironment induced by pancreatic cancers suppresses CD8+ CTL function through secretion of IL-10 and TGF- $\beta$ from Treg cells $[45,46]$. The accumulation of these immune suppressive cells in pancreatic cancer might be closely related to the extent of disease and correlated well with disease stage. Therefore, immunotherapies that struggle against pancreatic cancer cells with antigen-specific CTLs as well as depletion of Treg cells may tip the balance in favor of immunostimulation. Currently, the field of cancer immunotherapy using peptideor cell- (DC or whole tumor cell)-based approaches is in an active state of preclinical and clinical investigations.

\section{Peptide Vaccines}

TCR engagement by peptide/MHC constitutes the main signal for the activation of naive CD4+ and CD8+ T cells. Although $\mathrm{CD} 8+$ naive $\mathrm{T}$ cells recognize peptides derived from TAAs bound by MHC class I molecules, it is not sufficient to initiate a productive generation of antigen-specific CTLs. Full induction of CTLs requires additional signals driven by costimulatory molecules on DCs. CD8+ CTLs can respond to TAAs-derived peptides presented in the context of MHC class I molecules on tumor cells. Therefore, many investigators have tried to identify MHC class I-binding peptides that could be utilized to develop tumor vaccines for treatment of cancer patients. Peptide-based cancer vaccines are preparations made from antigenic protein fragments (called epitopes) that represent the minimal immunogenic region of antigens $[47,48]$. The increased understanding of antigen recognition at molecular level has resulted in the development of rationally designed peptide vaccines. Indeed, the peptide-based cancer vaccines for pancreatic cancer have undergone phase I/II clinical trials $[49,50]$. The major advantages of peptide vaccines are that they are simple, safe, stable, and economical. Induction of CTLs need peptides derived from TAAs to be presented on the surface of APCs such as DCs in the context of HLA molecules. However, several obstacles limit the widespread usefulness of peptide vaccines. The drawback of this strategy comes from numerous factors: (i) a limited number of known synthesized 


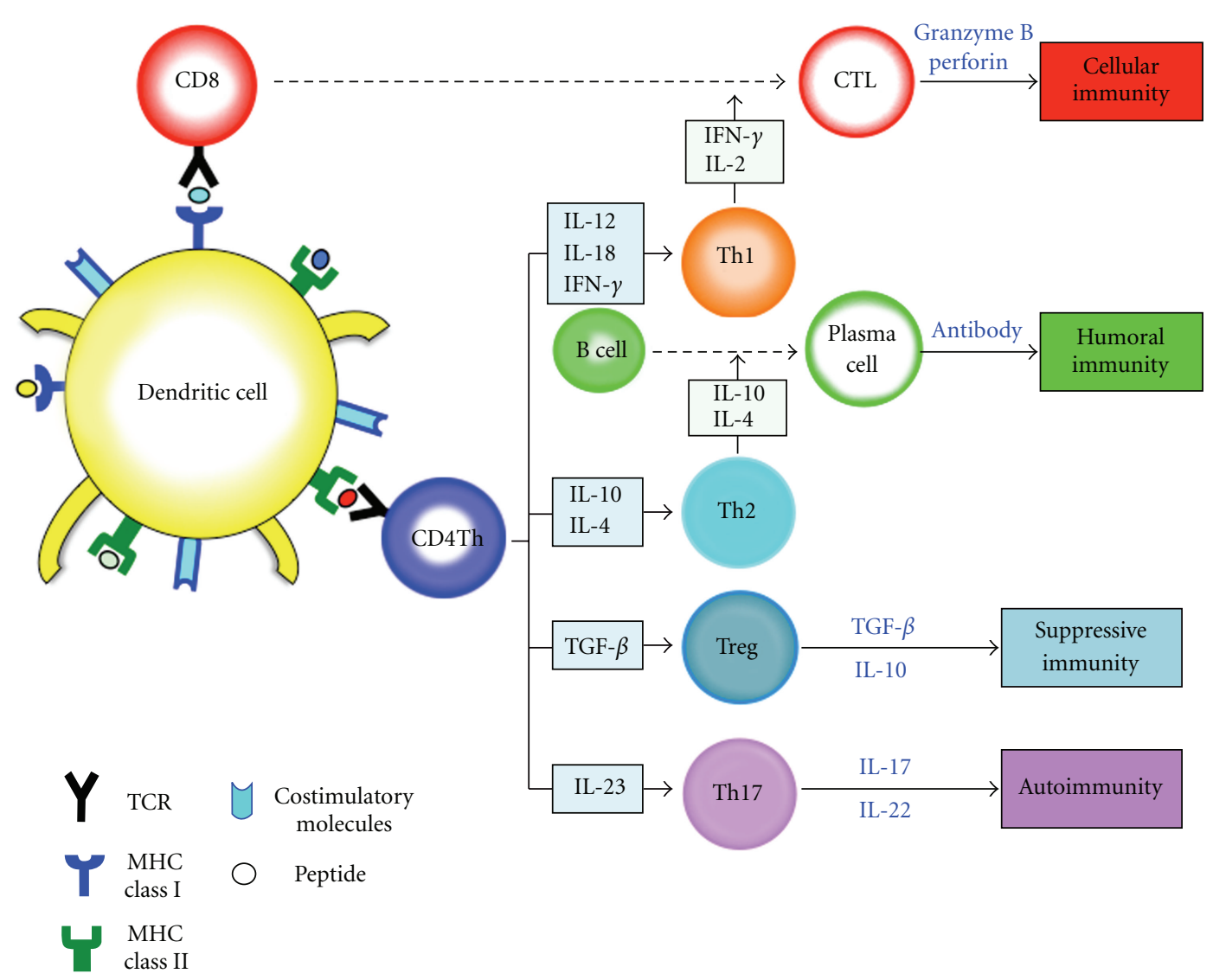

Figure 2: Immune homeostasis. Upon TCR-mediated cell activation, naive CD4 T cells can differentiate into four major lineages, Th1, Th2, Th17, and Treg cells that participate in different types of immune responses. The Th1 cells produce IFN- $\gamma$ and IL-2, resulting in induction of CD8+ CTLs. Th2 cells secrete IL-4 and IL-10. The Th2 response is associated with the humoral, antibody-based antitumor response. Th17 cells secrete IL-17 and IL-22, eliciting tissue inflammation implicated in autoimmunity. Treg cells that secrete TGF- $\beta$ and IL-10 suppress effector Th1 or Th2 cells.

short peptides cannot be available in many HLA molecules [51-53], (ii) CD8+ CTLs may be ineffective in reacting with pancreatic cancer cells downregulated by certain tumor antigens and MHC class I molecules, which may appear during the course of tumor progression [22], (iii) impaired function of APCs in patients with advanced pancreatic cancer [54, 55], and (iv) MDSCs or Treg cells in tumor environment produce immunosuppressive cytokines such as IL-10 and TGF- $\beta$ [26].

Vaccination with synthetic peptides, particularly MHC class I-binding epitopes, has been performed in pancreatic cancer (Table 1). In a phase I/II trials, vaccination for the patients with advanced pancreatic cancer using mutant Kras [39, 56, 57], MUC1 [58, 59], or telomerase [60] peptides was significantly associated with immune responses. Gjertsen et al. [56] first reported mutant K-ras peptide vaccines for pancreatic cancer. Since native epitopes have relatively low immunogenicity, granulocyte-macrophage colony-stimulating factor (GM-CSF) was applied to achieve efficient vaccination in the study. Among 48 patients with pancreatic cancer (10 surgically resected and 38 with advanced disease), vaccination of mutant K-ras peptides in combination with GMCSF resulted in immune responses and prolonged survival.
Moreover, another group also reported that vaccination of 24 patients with resected pancreatic cancer with K-ras peptide in combination with GM-CSF proved to be safe without tumor regression [57]. In an MUC1 peptide vaccine, vaccination of 16 patients with resected or locally advanced pancreatic cancer with 100 mer MUC1 peptide and SBAS2 adjuvant resulted in low but detectable MUC1-specific immune responses in some patients [59]. Moreover, vaccination with 100 mer MUC1 peptide and incomplete Freund's adjuvant resulted in increased circulating anti-MUC1 IgG antibody in some patients [58]. In addition, augmented immune responses and prolonged survival were observed following vaccination of advanced pancreatic cancer patients with telomerase peptide and GM-CSF [60]. Recent protocols using personalized peptides demonstrated frequent induction of tumor reactive $\mathrm{T}$ cells [61]. In this regimen, prevaccination peripheral blood mononuclear cells (PBMCs) were screened for their reactivity in vitro to each peptide in patients, and only the reactive peptides were vaccinated to 11 patients with advanced pancreatic cancer. In the personalized peptide vaccines, augmented immune responses to at least one of peptides used for vaccination were observed in 


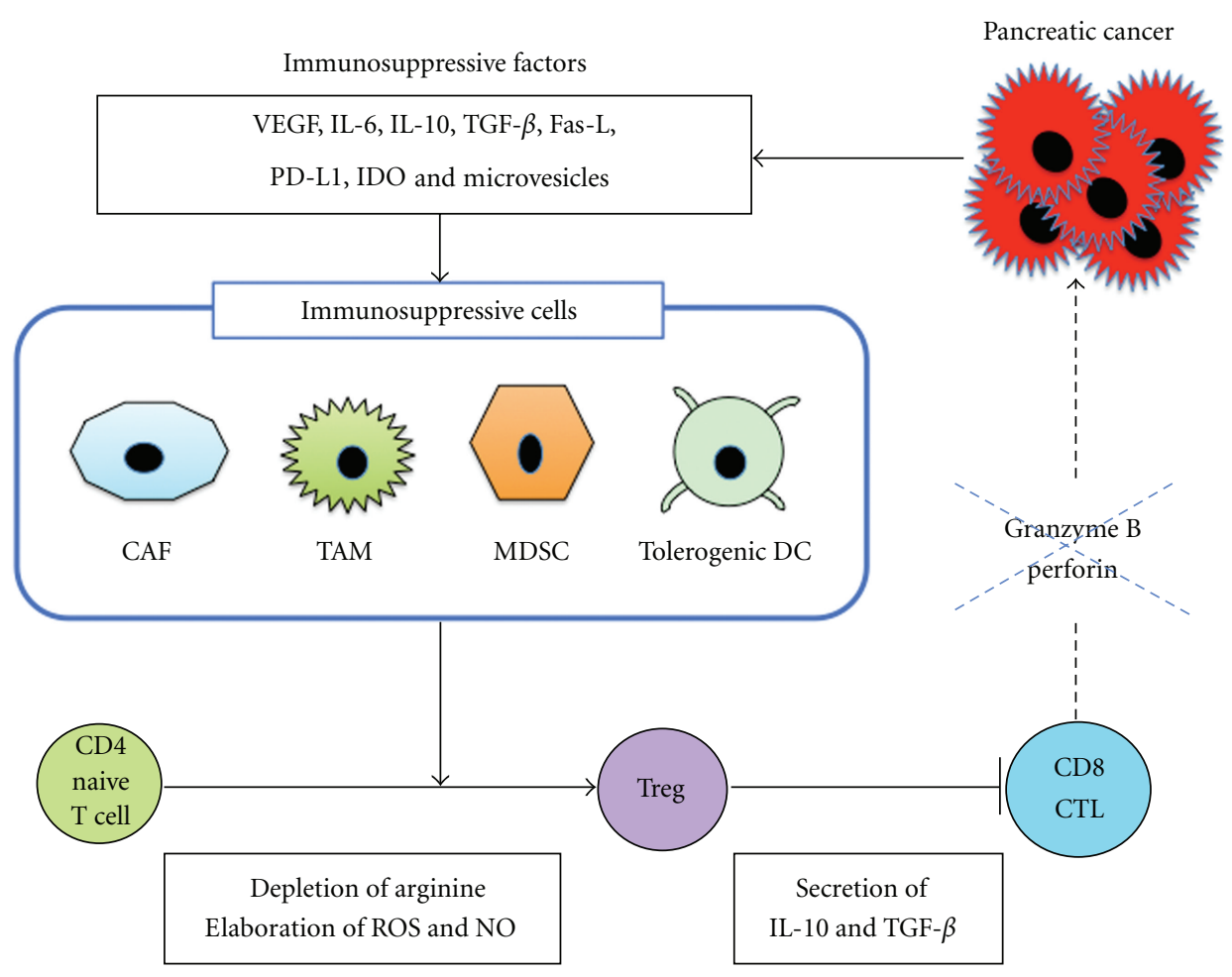

FIgURE 3: Pancreatic cancers induce an immunosuppressive tumor microenvironment. Pancreatic cancer cells secrete various immunosuppressive factors such as VEGF, IL-6, IL-10, TGF- $\beta$, Fas-L, IDO, PD-L1, and microvesicles, all of which promote the accumulation of TAM, MDSC, or tolerogenic DC. These immunosuppressive cells inhibit antitumor immunity by various mechanisms, including depletion of arginine and elaboration of ROS and NO. An immunosuppressive tumor microenvironment induced by pancreatic cancers suppresses CD8+ CTL function through secretion of IL-10 and TGF- $\beta$ from Treg cells. All contribute to pancreatic cancer-induced immune suppression.

the postvaccination PBMCs [62]. In these all peptide vaccines, only a limited success has occurred in clinical trials. The short peptide can be loaded exogenously in MHC class I molecules and presented by DCs within a few days after injection to the patients. Moreover, the short peptide vaccines are not immunogenic enough. The more attractive peptide-based vaccines may be synthetic long peptides to induce antigen-specific polyclonal CD4+ and CD8+ T cells [63]. As long synthetic peptides are not able to bind directly on MHC class I or II molecules on DCs, they need to be taken up, processed, and presented by DCs. The long peptide vaccines can present MHC class I- and II-restricted epitopes long time, thus eliciting both CD4- and CD8mediated immune recognition [64]. Peptide vaccines aimed at the treatment of established cancer may require long-lived presentation of epitopes by MHC class I and II molecules on appropriately activated DCs. Such presentation is essential for induction of robust therapeutic T-cell responses.

In a phase I study using long synthetic mutant ras peptides, Weden et al. [65] treated 23 patients who were vaccinated after surgical resection for pancreatic cancer. Longterm immunological memory responses to the vaccines were observed. Strikingly, 10-year survival was 20\% (four patients out of 20 evaluable) versus zero (0/87) in a cohort of nonvaccinated patient treated in the same period. Cancer vaccines for pancreatic cancer may be tested to prevent recurrence and metastasis after surgical resection. Furthermore, peptide vaccines to boost immune responses in combination with chemotherapy to overcome robust cancers may be the key elements for the development of therapeutic cancer vaccines. Indeed, Wobser et al. [40] reported a case of complete remission (CR) of liver metastasis of pancreatic cancer refractory to gemcitabine chemotherapy under vaccination with a survivin peptide.

\section{Whole Tumor Cell Vaccines}

Despite the identification of peptides, autologous whole tumor cells remain a potent vehicle for generating antitumor immunity. This is because tumor cells express all relevant candidate TAAs, including both known and unidentified. In the clinical setting, an autologous whole tumor cell vaccine depends on the availability of adequate numbers of tumor cells. As only $10-15 \%$ of pancreatic cancer patients diagnosed are eligible for surgical, autologous pancreatic cancer cells may not be provided in most of the patients. Moreover, even if the patients are treated by surgical resection, it is difficult to prepare sufficient numbers of tumor cells due to the length of culture time and potential contamination of bacteria and fungus $[55,66]$. To circumvent this problem, 
TABle 1: Peptide vaccines.

\begin{tabular}{|c|c|c|c|c|}
\hline Patients & Peptide vaccine & Adjuvant & Response & Ref. \\
\hline $\begin{array}{l}10 \text { resected and } 38 \\
\text { advanced } \\
\text { pancreatic caner }\end{array}$ & Mutant K-ras peptide & GM-CSF & $\begin{array}{l}\text { Immune response to the peptide vaccine } \\
\text { showed prolonged survival compared to } \\
\text { nonresponders. } \\
\text { K-ras-specific T cells were selectively } \\
\text { accumulated in the tumor. }\end{array}$ & {$[56]$} \\
\hline $\begin{array}{l}24 \text { resected } \\
\text { pancreatic cancer }\end{array}$ & Mutant K-ras peptide & GM-CSF & $\begin{array}{l}\text { No elicitable immunogenicity and unproven } \\
\text { efficacy was observed. }\end{array}$ & {$[57]$} \\
\hline $\begin{array}{l}16 \text { resected or } \\
\text { locally advanced } \\
\text { pancreatic cancer }\end{array}$ & 100 mer MUC1 peptide & SB-AS2 adjuvant & $\begin{array}{l}\text { Detectable MUC1-specific humoral and T-cell } \\
\text { responses were detected in some patients. }\end{array}$ & {$[59]$} \\
\hline $\begin{array}{l}6 \text { advanced } \\
\text { pancreatic cancer }\end{array}$ & 100 mer MUC1 peptide & $\begin{array}{l}\text { Incomplete Freund's } \\
\text { adjuvant }\end{array}$ & $\begin{array}{l}\text { One patient showed a tendency for increased } \\
\text { circulating anti-MUC1 IgG antibody. }\end{array}$ & {$[58]$} \\
\hline $\begin{array}{l}48 \text { advanced } \\
\text { pancreatic cancer }\end{array}$ & Telomerase peptide & GM-CSF & $\begin{array}{l}\text { Immune responses were observed in } 24 \text { of } 38 \\
\text { evaluable patients. } \\
\text { One-year survival for the evaluable patients in } \\
\text { the intermediate dose group was } 25 \% \text {. }\end{array}$ & {$[60]$} \\
\hline $\begin{array}{l}11 \text { advanced } \\
\text { pancreatic cance }\end{array}$ & $\begin{array}{l}\text { Personalized peptide } \\
\text { vaccine }\end{array}$ & & $\begin{array}{l}\text { The } 6 \text { - and } 12 \text {-month survival rates for } \\
\text { patients who received }>3 \text { vaccinations }(n=10) \\
\text { were } 80 \% \text { and } 20 \% \text {, respectively. }\end{array}$ & {$[62]$} \\
\hline $\begin{array}{l}23 \text { resected } \\
\text { pancreatic cancer }\end{array}$ & Mutant ras long peptide & & $\begin{array}{l}\text { Seventeen of } 20 \text { evaluable patients }(85 \%) \\
\text { responded immunologically to the vaccine. } \\
\text { Ten-year survival was } 20 \% \text { (four patients out of } \\
20 \text { evaluable). }\end{array}$ & {$[65]$} \\
\hline $\begin{array}{l}1 \text { liver metastasis of } \\
\text { pancreatic cancer } \\
\text { refractory to } \\
\text { gemcitabine }\end{array}$ & Survivin peptide & & $\begin{array}{l}\text { The patient initially underwent partial } \\
\text { remission of liver metastasis which proceeded } \\
\text { after } 6 \text { months into a complete remission with } \\
\text { a duration of } 8 \text { months. }\end{array}$ & {$[40]$} \\
\hline
\end{tabular}

allogeneic tumor cell lines may be used instead of autologous tumor cells [66]. This strategy has numerous advantages: (i) allogeneic tumor cell lines are well characterized as TAA source, (ii) specific TAAs do not need to be identified for vaccination, (iii) allogeneic tumor cell lines, which shared with TAAs, can grow well in vitro; thus, there is no limiting factor for preparation of tumor cells, (iv) it is not necessary to determine HLA typing of patients and allogeneic tumor cells, because autologous DCs can process and present multiple TAAs from allogeneic tumor cells owing to crosspresentation in the context of appropriate MHC class I and II alleles, and (v) polyclonal antigen-specific CD4+ and CD8+ $\mathrm{T}$ cells can be generated, which may protect against tumor escape variants. While currently explored allogeneic approaches in whole tumor cell-based vaccination procedures represent an improvement in terms of standardization over their autologous counterparts, they nevertheless entail the culture of large batches of cells under good manufacturing practice (GMP) grade conditions. One of major challenges to develop an allogeneic tumor cell-based vaccine strategy is to overcome the potential hazards of fetal calf serum (FCS) that limit safety in clinical trials [55]. Optimization of these in vitro culture methodologies is required.

In clinical trials, allogeneic whole tumor cells (melanoma, prostate, and pancreatic cancer), transduced with GMCSF, have been applied clinically and shown to induce antitumor immunity [67-69]. In this trial, whole allogeneic tumor cells were genetically modified to secrete the immune stimulatory cytokine, GM-CSF, and then irradiated to prevent further cell division. GM-CSF is now recognized to be the crucial growth and differentiation factor for DCs. Therefore, this approach is based on the concept that GM-CSF is required at the site of the tumor to effectively prime TAAs-specific immunity. Allogeneic GM-CSF-secreting pancreatic cancer vaccine was conducted (Table 2 ). The vaccines induced systemic antitumor immunity against autologous pancreatic cancer cells [67]. The same group [70] administrated GMCSF-secreting allogeneic pancreatic cancer cells in sequence with cyclophosphamide in patients with advanced pancreatic cancer. The approach showed minimal treatment-related toxicity and mesothelin-specific T-cell responses. Moreover, combination of the vaccine and cyclophosphamide resulted in median survival in a gemcitabine-resistant population similar to chemotherapy alone. It was also reported that combination of the vaccines and chemoradiation demonstrated an overall survival that compares favorably with published data for resected pancreas cancer [69].

\section{DC-Based Vaccines}

DCs derive their potency from the prominent expression of MHC class I and II, costimulatory (CD80 and CD86), and adhesion molecules that provide secondary signals for the activation of naive CD4+ and CD8+ T cells [24]. Therefore, 
TABLE 2: Whole tumor cell-based vaccines.

\begin{tabular}{|c|c|c|c|c|}
\hline Patients & $\begin{array}{l}\text { Whole tumor cell-based } \\
\text { vaccines }\end{array}$ & Combination & Response & Ref \\
\hline \multirow[t]{2}{*}{$\begin{array}{l}14 \text { resected } \\
\text { pancreatic cancer }\end{array}$} & \multirow[t]{2}{*}{$\begin{array}{l}\text { Allogeneic } \\
\text { GM-CSF-secreting } \\
\text { pancreatic cancer cell }\end{array}$} & & $\begin{array}{l}\text { Vaccination induced increased } \\
\text { delayed-type hypersensitivity (DTH) } \\
\text { responses to autologous tumor cells in } \\
\text { three patients. }\end{array}$ & \multirow[t]{2}{*}{ [67] } \\
\hline & & & $\begin{array}{l}3 \text { patients also seemed to have had an } \\
\text { increased disease-free survival time, } \\
\text { remaining disease-free at least } 25 \text { months } \\
\text { after diagnosis. }\end{array}$ & \\
\hline \multirow[t]{2}{*}{$\begin{array}{l}30 \text { advanced } \\
\text { pancreatic cancer }\end{array}$} & \multirow[t]{2}{*}{$\begin{array}{l}\text { Allogeneic } \\
\text { GM-CSF-secreting } \\
\text { pancreatic cancer cell }\end{array}$} & \multirow[t]{2}{*}{$\begin{array}{l}\text { Vaccine alone or in sequence } \\
\text { with cyclophosphamide }\end{array}$} & $\begin{array}{l}\text { CD8+ T-cell responses to HLA class } \\
\text { I-restricted mesothelin epitopes were } \\
\text { identified predominantly in patients } \\
\text { treated with cyclophosphamide and } \\
\text { immunotherapy. }\end{array}$ & \multirow[t]{2}{*}{ [70] } \\
\hline & & & $\begin{array}{l}\text { Cyclophosphamide-modulated } \\
\text { immunotherapy resulted in median } \\
\text { survival in a gemcitabine-resistant } \\
\text { population similar to chemotherapy } \\
\text { alone. }\end{array}$ & \\
\hline
\end{tabular}

a major area of investigation in cancer immunotherapy involves the design of DCs-based cancer vaccines [71, 72]. Several strategies to deliver TAAs including defined or whole antigens to DCs have been developed to generate a potent CTL response against tumor cells in murine and human systems (Figure 4). DCs have been pulsed with synthetic peptide derived from the known tumor antigens [73], tumor cell lysates [74], apoptotic tumor cells [75], or RMA derived from tumor antigens [76] and transfected with whole tumor cell DNA [77] or RNA [78]. Moreover, DCs have been fused with tumor cells to induce antigen-specific polyclonal CTL responses [79]. In the DC/tumor cell fusion approach, whole TAAs including those known and those yet unidentified are processed endogenously and presented by MHC class I and II pathways in the context of costimulatory signals [80-82]. Although DC-based vaccines have proven clinically safe and efficient to induce tumor-specific immune responses, only a limited number of objective clinical responses have been reported in cancer patients [83-86]. These relatively disappointing results have prompted the evaluation of multiple approaches to improve the efficacy of DC-based vaccines.

DC-based vaccines have also been used for pancreatic cancer (Table 3). The human tumor antigen mucin, encoded by the gene MUC1, is a high-molecular-weight glycoprotein that is overexpressed in adenocarcinomas including pancreatic cancer and hematological cancers and can be recognized by cytotoxic T lymphocytes (CTLs) and monoclonal antibodies [87]. A vaccine consisting of liposomal MUC1transfected autologous DCs was evaluated in a clinical phase I/II trial. In MUC1 peptide-loaded DC vaccines in pancreatic and biliary cancer patients following resection of their primary tumors, 4 of the 12 patients followed for over four years were alive, all without evidence of recurrence [88]. Moreover, MUC1-specific immune responses were also observed even in patients with pretreated and advanced disease, following immunization with DCs transfected with MUC1 cDNA [89].
As hTERT is the catalytic subunit of telomerase and a prototype for a novel class of universal tumor antigens, it is one of widely applicable targets recognized by CTLs [90]. In the human system, DCs transfected with hTERT mRNA have previously been shown to induce CTL responses to hTERT in vitro [91]. Furthermore, findings from initial clinical trials demonstrate that hTERT-specific immune responses can be safely induced in cancer patients [92]. A patient who could not continue chemotherapy due to sever neutropenia had been treated with autologous DCs transfected with hTERT mRNA for 3 years and resulted in no evidence of active disease. Moreover, the complete remission (CR) was associated with induction of hTERT-specific CD4+ and CD8+ T cells [93].

\section{DNA Vaccines}

Cell-based cancer vaccines cause antitumor immune response at first. But they become less effective over time because the induced immune system recognizes them as foreign and quickly destroys them. DNA vaccines that consist of TAAs and additional immune-stimulatory factors have an advantage over cell-based vaccines because it can provide prolonged antigen expression, leading to amplification of immune responses and inducing memory responses against weakly immunogenic TAAs. Moreover, as DNA might be taken up by cells and the encoded antigen is processed through both endogenous and exogenous pathways, DNA vaccines that administered via intramuscular injection allow for an immune response to multiple potential epitopes within an antigen to be generated regardless of the patient's MHC profile [95]. DNA vaccines are now being studied in clinical trials for melanoma and prostate cancer. In pancreatic cancer, DNA vaccination targeting MUC1 [96] or survivin [97] has been studied in murine models and resulted in antitumor immune responses. 


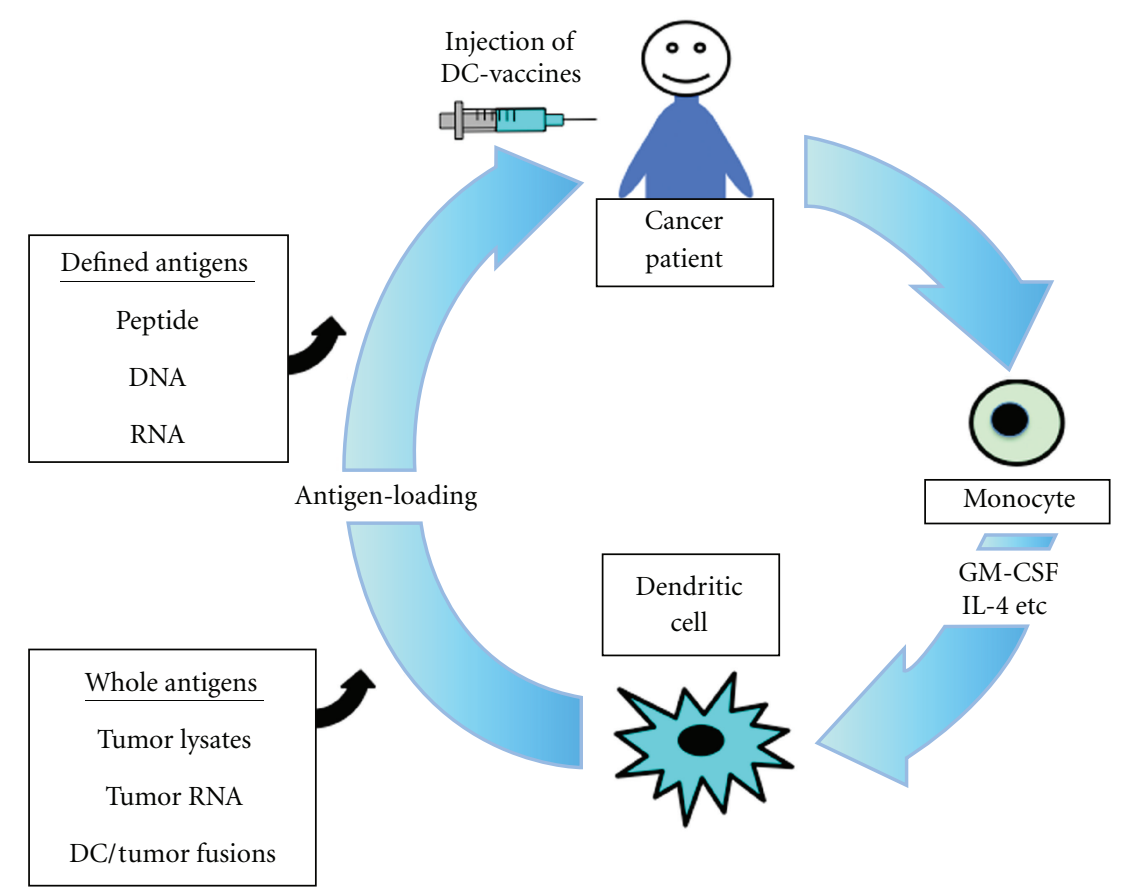

FIGURE 4: Strategies to deliver defined or whole antigens to DCs. DCs used for cancer vaccines have been generated from the peripheral blood monocytes of the patients using cytokines including GM-CSF and IL-4. To generate antigen-specific CTL response against tumor cells, DCs have been loaded with defined or whole tumor-associated antigens. For example, DCs loaded with synthetic peptide, antigenic DNA, or RNA have been used. Moreover, whole tumor-associated antigens including defined and unidentified have been also loaded to DCs.

TABLe 3: DC-based vaccines.

\begin{tabular}{|c|c|c|c|}
\hline Patients & DC-based vaccines & Response & Ref \\
\hline $\begin{array}{l}12 \text { pancreatic and biliary } \\
\text { cancer patients with resected } \\
\text { tumors }\end{array}$ & MUC1 peptide-loaded DC & $\begin{array}{l}4 \text { of the } 12 \text { patients followed for over four years } \\
\text { were alive. }\end{array}$ & [88] \\
\hline \multirow{2}{*}{$\begin{array}{l}10 \text { patients with advanced } \\
\text { breast, pancreatic, or papillary } \\
\text { cancer }\end{array}$} & \multirow[t]{2}{*}{$\begin{array}{l}\text { DC transfected with MUC1 } \\
\text { cDNA }\end{array}$} & $\begin{array}{l}\text { A vaccine-specific delayed-type } \\
\text { hypersensitivity (DTH) reaction was observed } \\
\text { in } 3 \text { out of } 10 \text { patients. }\end{array}$ & \multirow[t]{2}{*}{89} \\
\hline & & $\begin{array}{l}4 \text { patients showed a } 2 \text { - to } 10 \text {-fold increase in } \\
\text { the frequency ofMUC1-specific } \\
\text { IFN-gamma-secreting CD } 8+\text { T cells. }\end{array}$ & \\
\hline \multirow{2}{*}{$\begin{array}{l}1 \text { patient who could not } \\
\text { continue chemotherapy due } \\
\text { to sever neutropenia }\end{array}$} & \multirow{2}{*}{$\begin{array}{l}\text { DC transfected with hTERT } \\
\text { mRNA }\end{array}$} & $\begin{array}{l}\text { The patient showed no evidence of active } \\
\text { disease based on PET/CT scans. }\end{array}$ & \multirow[t]{2}{*}[93]{} \\
\hline & & $\begin{array}{l}\text { The patient developed an immune response } \\
\text { against several hTERT-derived Th and CTL } \\
\text { epitopes. }\end{array}$ & \\
\hline \multirow{2}{*}{$\begin{array}{l}49 \text { patients with advanced } \\
\text { pancreatic cancer refractory to } \\
\text { standard chemotherapy }\end{array}$} & $\begin{array}{l}\text { Peptide (WT1, MUC1, CEA, } \\
\text { and CA125)-loaded DC }\end{array}$ & $\begin{array}{l}2 \text { patients showed complete remission }(\mathrm{CR}), 5 \\
\text { partial remission }(\mathrm{PR}) \text { and } 10 \text { stable disease } \\
(\mathrm{SD}) \text {. }\end{array}$ & \multirow[t]{2}{*}[94]{} \\
\hline & Gemcitabine/S-1 & Median survival time was 360 days. & \\
\hline
\end{tabular}

\section{Chemotherapy and Immunotherapy}

Recently, new paradigms have emerged in the field of cancer vaccine research. In particular, the potential use of combination therapies that incorporate immune modulators and standard radio- and chemotherapy to synergize with cancer vaccines has been discussed. Cytotoxic chemotherapy is generally considered immunosuppressive, because of its toxicity for dividing cells in the bone marrow and peripheral lymphoid tissue. Therefore, the combination of cancer vaccines with chemotherapies has been considered to be inappropriate because the immunosuppressive effects of the chemotherapy would negate the efficacy of cancer vaccines. However, increasing evidences have been mounting to suggest that immunotherapy has the possibility of achieving better success when used in combination with conventional 
chemotherapy $[98,99]$. A standard cytotoxic agent, gemcitabine, not only exerts direct antitumor activity, but also mediates immunological effects relevant for cancer immunotherapy [100-102]. Cross-presentation of TAAs by DCs is essential for induction of augment CTL responses. Treatment of cancer cells and DCs with gemcitabine results in enhanced cross-presentation of TAAs by DCs, CTL expansion, and infiltration of the tumor, all of which are associated with augmented CTL [103-106]. The increase in cross-presentation did not lead to tolerance $[104,105]$. Moreover, gemcitabine reduced the number of myeloid suppressor cells but did not reduce $\mathrm{CD} 4+\mathrm{T}$ cells, $\mathrm{CD} 8+\mathrm{T}$ cells, NK cells, macrophages, or B cells [107]. Therefore, gemcitabine may be not immunosuppressive and enhance responses to immunotherapy administered to activate or support immune responses directed toward driving effector immunity to pancreatic cancer cells [108]. Indeed, combination of DCs pulsed tumor cells with gemcitabine augmented therapeutic efficacy in vivo in a murine pancreatic cancer model [109]. Moreover, Ramakrishnan et al. [110] have reported that chemotherapeutic agents caused upregulation of cation-independent mannose 6-phosphate receptor (CI-MPR) expression on cancer cells and a concurrent increase in the uptake of granzyme B by activated CTLs in a large number of neighboring cancer cells. As a result, CTLs may cause apoptosis in large numbers of cancer cells manifesting in a clinically evident antitumor effect. Thus, such a combination therapy may be very promising approach to the treatment of patients with advanced pancreatic cancers.

Tumors that develop drug resistance would still be a suitable target for immunotherapy [111]. It has been well known that the majority of patients with advanced pancreatic cancer that respond initially to standard chemotherapies ultimately undergo relapse due to the survival of small populations of cells with cancer-initiating/cancer stem cell (CSC) fraction [112]. These CSCs are a subpopulation of the tumor more capable than other cells to self-propagate, initiate new tumors differentiate into bulk tumor, and therefore sustain tumor growth. Although chemotherapy kills most cancer cells, it is believed to leave CSCs behind, which might be an important mechanism of resistance [113]. CSCs are resistant to a variety of treatments, including chemotherapy and radiotherapy, with varied mechanisms of resistance, including high expression of ATP-binding cassette $(\mathrm{ABC})$ drug transporters, an active DNA-repair capacity, and a resistance to apoptosis $[113,114]$. Recently, CSCs have been isolated from various types of malignancies, including pancreatic cancer [114-118]. According to the manner of expression in CSCs, TAAs can be classified into two categories: (i) CSCspecific antigens, such as SOX2 [119] and ALDH1A1 [120] and (ii) shared antigens, such as CEP55 [121], MUC1 [122], or WT1 $[123,124]$ between CSCs and more differentiated subpopulations. Several methods to isolate CSC have been reported, including cell surface markers such as CD44, CD24, CD133, or epithelial-specific antigen (ESA) and side population (SP) cells using Hoechst 33342 dye [115, $119,120]$. Purified tumor stem cells from a patient can be used to immunize the patient or to activate the donor's immune cells against the tumor stem cells [113]. Therefore, the development of strategies that target the CSC population by immunotherapy may be highly desirable. Success of these potential therapies will depend on how well immunological responses to CSCs can be modulated by vaccines. We recently generated hybrid cells by fusing DCs and CSCs to activate potent CSC-specific CTL responses. The DC/CSC fusions induced proliferation of $\mathrm{T}$ cells with high expression levels of IFN- $\gamma$ and enhanced killing of CSCs in vitro [111]. Moreover, peptide-based cancer vaccines or adoptive cell transfer of the CSC-specific CTL clone is a possible approach for targeting chemotherapy-resistant CSCs [120]. These findings open a novel field of investigations for future clinical trial design, taking into account the immunostimulatory capacity of chemotherapy such as gemcitabine, and using them in combined chemoimmunotherapy strategies in patients with pancreatic cancer $[103,104,106,125,126]$. Moreover, it seems that a period of time exists between the start of chemotherapy and immunotherapy. As the fact that even without chemotherapy, antitumor immune responses induced by immunotherapy cannot be sustained for a long period of time in patients with cancer. It would be important to establish the optimum timing and scheduling of immunotherapy and chemotherapy, to identify whether this synergistic effect is limited to a specific type of chemotherapy and whether immunotherapy can also augment the clinical effect of chemotherapy [44, 110, 127]. A combined approach of conventional therapies such as radiation or chemotherapy kills the bulk of tumor cells, and CSC-reactive CTL that target CSC fraction may represent a more promising approach for the treatment of patients with advanced pancreatic cancer (Figure 5).

In clinical trials, patients with advanced pancreatic cancer had been treated by combination therapy of standard cytotoxic agent, gemcitabine with personalized peptides $[49,128]$, or vascular endothelial growth factor receptor 2 (VEGFR2) [50]. The reactive personalized peptides (maximum of 4 kinds of peptides) were administered with gemcitabine to patients with nonresectable pancreatic cancer. Median survival time of all 21 patients was 9.0 months with a one-year survival rate of $38 \%$. Immune boosting in both cellular and humoral responses was well correlated with overall survival. Moreover, in combination therapy of peptide for VEGFR2 with gemcitabine for patients with metastatic and unresectable pancreatic cancer, the median overall survival time of all 18 patients who completed at least one course of the treatment was 8.7 months. VEGFR2specific CTL responses could be induced by the combination therapy. The survival benefit of combination therapy of peptide vaccines and gemcitabine in comparison with gemcitabine alone needs to be confirmed in randomized clinical trials. Similar findings are also observed in combination therapy of DCs-based cancer vaccines and gemcitabine. Five patients with locally advanced pancreatic cancer had been treated with gemcitabine, OK-432-stimulated DCs injected into the tumor sites, and intravenous infusion of lymphocyte-activated killer cells stimulated with antiCD3 monoclonal antibody [129]. In this report, 1 patient had partial remission (PR) and 2 had long stable disease (SD) more than 6 months. More recently, we also reported 


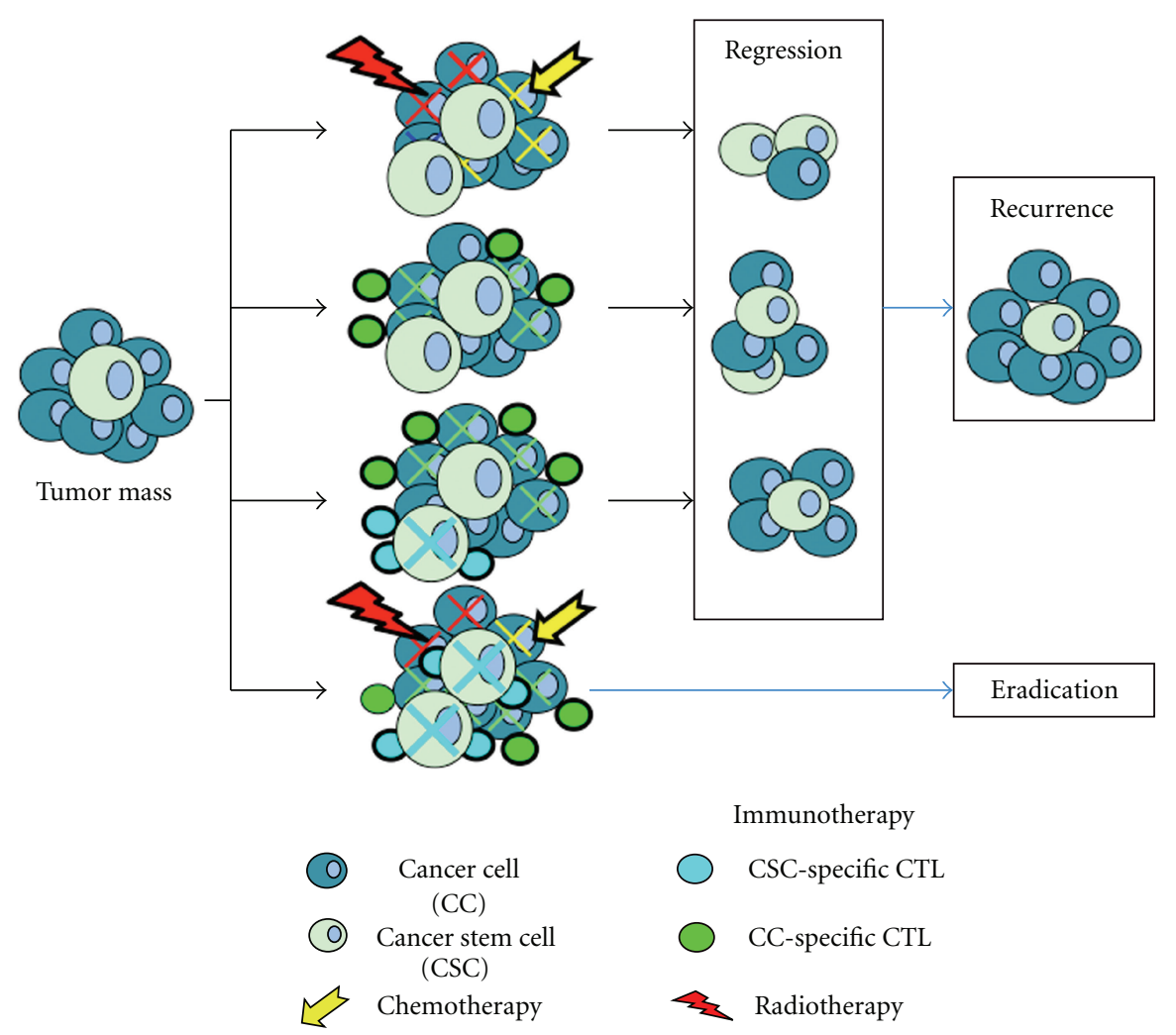

FIGURE 5: Combination therapies of immunotherapy and standard radio- and chemotherapy. Currently applied standard therapies such as radio- and chemotherapy target bulk cancer cells that are less resistant than cancer stem cells. This leads to initial regression of the tumor mass but eventually regrowth from residual CSCs. Combined therapies of standard therapies and immunotherapeutic approach targeting CSCs would cut off the rejuvenating supply of CSCs and resulted in tumor eradication.

that DC vaccine-based immunotherapies combined with gemcitabine/S-1 were effective in patients with advanced pancreatic cancer refractory to standard chemotherapy [94]. As both WT1 and MUC1 are one of the excellent TAAs for the target of immunotherapy and are frequently expressed in pancreatic cancer cells $[36,37,123,130], 38$ out of 49 patients had received vaccination with WT1 peptide-pulsed DCs with or without combination of other peptides such as MUC1, CEA, and CA125 in this report. Prior to this combination therapy, 46 out of 49 patients had been treated with chemotherapy, radiotherapy, heavy particle radiotherapy, or hyperthermia but elicited no significant effects. In spite of these handicapped conditions, surprisingly, of 49 patients, 2 patients showed CR, $5 \mathrm{PR}$, and $10 \mathrm{SD}$, and median survival time was 360 days. The use of DCs-based vaccines in direct combination with chemotherapy in patients with pancreatic cancer might become a veritable option for the treatment of patients with advanced-stage cancer. Indeed, gemcitabine enhanced WT1 expression in human pancreatic cancer cells and sensitized the pancreatic cancer cells with WT1-specific T cell-mediated antitumor responses [131]. Although the concept is far from being firmly established, these reports may be sufficient to provide a platform for the combination of immunotherapy with chemotherapy. Evaluation is warranted to examine the effect of the approach on disease-free survival and overall survival.

\section{Disclosure}

The authors have no relevant affiliations or financial involvement with any organization or entity with a financial interest in or financial conflict with the subject matter or materials discussed in the paper.

\section{Acknowledgments}

This work has been supported by Foundation for Promotion of Cancer Research, Mitsui Life Social Welfare Foundation, Grants-in-Aid for Scientific Research (C) from the Ministry of Education, Cultures, Sports, Science and Technology of Japan, Grant-in-Aid of the Japan Medical Association, and Takeda Science Foundation.

\section{References}

[1] A. Jemal, R. Siegel, J. Xu, and E. Ward, "Cancer statistics, 2010," CA Cancer Journal for Clinicians, vol. 60, no. 5, pp. 277-300, 2010.

[2] S. F. Sener, A. Fremgen, H. R. Menck, and D. P. Winchester, "Pancreatic cancer: a report of treatment and survival trends for 100,313 patients diagnosed from 1985-1995, using the National Cancer Database," Journal of the American College of Surgeons, vol. 189, no. 1, pp. 1-7, 1999. 
[3] J. P. Neoptolemos, D. D. Stocken, H. Friess et al., "A randomized trial of chemoradiotherapy and chemotherapy after resection of pancreatic cancer," New England Journal of Medicine, vol. 350, no. 12, pp. 1200-1210, 2004.

[4] H. A. Burris III, M. J. Moore, J. Andersen et al., "Improvements in survival and clinical benefit with gemcitabine as first- line therapy for patients with advanced pancreas cancer: a randomized trial," Journal of Clinical Oncology, vol. 15, no. 6, pp. 2403-2413, 1997.

[5] A. M. Storniolo, S. R. B. Allerheiligen, and H. L. Pearce, "Preclinical, pharmacologic, and phase I studies of gemcitabine," Seminars in Oncology, vol. 24, no. 2, supplement 7, pp. S7-2S7-7, 1997.

[6] J. D. Berlin, P. Catalano, J. P. Thomas, J. W. Kugler, D. G. Haller, and A. B. Benson III, "Phase III study of gemcitabine in combination with fluorouracil versus gemcitabine alone in patients with advanced pancreatic carcinoma," Journal of Clinical Oncology, vol. 20, no. 15, pp. 3270-3275, 2002.

[7] C. M. R. Lima, M. R. Green, R. Rotche et al., "Irinotecan plus gemcitabine results in no survival advantage compared with gemcitabine monotherapy in patients with locally advanced or metastatic pancreatic cancer despite increased tumor response rate," Journal of Clinical Oncology, vol. 22, no. 18, pp. 3776-3783, 2004.

[8] C. Louvet, R. Labianca, P. Hammel et al., "Gemcitabine in combination with oxaliplatin compared with gemcitabine alone in locally advanced or metastatic pancreatic cancer: results of a GERCOR and GISCAD phase III trial," Journal of Clinical Oncology, vol. 23, no. 15, pp. 3509-3516, 2005.

[9] H. Oettle, D. Richards, R. K. Ramanathan et al., "A phase III trial of pemetrexed plus gemcitabine versus gemcitabine in patients with unresectable or metastatic pancreatic cancer," Annals of Oncology, vol. 16, no. 10, pp. 1639-1645, 2005.

[10] G. K. Abou-Alfa, R. Letourneau, G. Harker et al., "Randomized phase III study of exatecan and gemcitabine compared with gemcitabine alone in untreated advanced pancreatic cancer," Journal of Clinical Oncology, vol. 24, no. 27, pp. 44414447, 2006.

[11] S. R. Bramhall, J. Schulz, J. Nemunaitis, P. D. Brown, M. Baillet, and J. A. Buckels, "A double-blind placebo-controlled, randomised study comparing gemcitabine and marimastat with gemcitabine and placebo as first line therapy in patients with advanced pancreatic cancer," British Journal of Cancer, vol. 87, no. 2, pp. 161-167, 2002.

[12] E. Van Cutsem, H. van de Velde, P. Karasek et al., "Phase III trial of gemcitabine plus tipifarnib compared with gemcitabine plus placebo in advanced pancreatic cancer," Journal of Clinical Oncology, vol. 22, no. 8, pp. 1430-1438, 2004.

[13] P. A. Philip, J. Benedetti, C. L. Corless et al., "Phase III study comparing gemcitabine plus cetuximab versus gemcitabine in patients with advanced pancreatic adenocarcinoma: Southwest Oncology Group-directed intergroup trial S0205," Journal of Clinical Oncology, vol. 28, no. 22, pp. 36053610, 2010.

[14] E. Van Cutsem, C. Verslype, and P. A. Grusenmeyer, "Lessons learned in the management of advanced pancreatic cancer," Journal of Clinical Oncology, vol. 25, no. 15, pp. 1949-1952, 2007.

[15] P. A. Philip, "Improving treatment of pancreatic cancer," The Lancet Oncology, vol. 9, no. 1, pp. 7-8, 2008.

[16] S. Cascinu, R. Berardi, R. Labianca et al., "Cetuximab plus gemcitabine and cisplatin compared with gemcitabine and cisplatin alone in patients with advanced pancreatic cancer: a randomised, multicentre, phase II trial," The Lancet Oncology, vol. 9, no. 1, pp. 39-44, 2008.

[17] M. J. Moore, D. Goldstein, J. Hamm et al., "Erlotinib plus gemcitabine compared with gemcitabine alone in patients with advanced pancreatic cancer: a phase III trial of the National Cancer Institute of Canada Clinical Trials Group," Journal of Clinical Oncology, vol. 25, no. 15, pp. 1960-1966, 2007.

[18] K. Tobita, H. Kijima, S. Dowaki et al., "Epidermal growth factor receptor expression in human pancreatic cancer: significance for liver metastasis," International Journal of Molecular Medicine, vol. 11, no. 3, pp. 305-309, 2003.

[19] S. Ueda, S. Ogata, H. Tsuda et al., "The correlation between cytoplasmic overexpression of epidermal growth factor receptor and tumor aggressiveness: poor prognosis in patients with pancreatic ductal adenocarcinoma," Pancreas, vol. 29, no. 1, pp. E1-E8, 2004.

[20] S. S. Ng, M. S. Tsao, T. Nicklee, and D. W. Hedley, "Effects of the epidermal growth factor receptor inhibitor OSI-774, Tarceva, on downstream signaling pathways and apoptosis in human pancreatic adenocarcinoma," Molecular Cancer Therapeutics, vol. 1, no. 10, pp. 777-783, 2002.

[21] T. Boon, P. G. Coulie, and B. Van den Eynde, "Tumor antigens recognized by T cells," Immunology Today, vol. 18, no. 6, pp. 267-268, 1997.

[22] T. A. Waldmann, "Immunotherapy: past, present and future," Nature Medicine, vol. 9, no. 3, pp. 269-277, 2003.

[23] R. M. Steinman and J. Swanson, "The endocytic activity of dendritic cells," Journal of Experimental Medicine, vol. 182, no. 2, pp. 283-288, 1995.

[24] R. M. Steinman, "The dendritic cell system and its role in immunogenicity," Annual Review of Immunology, vol. 9, pp. 271-296, 1991.

[25] F. Berard, P. Blanco, J. Davoust et al., "Cross-priming of naive CD8 T cells against melanoma antigens using dendritic cells loaded with killed allogeneic melanoma cells," Journal of Experimental Medicine, vol. 192, no. 11, pp. 1535-1544, 2000.

[26] O. J. Finn, "Cancer immunology," New England Journal of Medicine, vol. 358, no. 25, pp. 2704-2715, 2008.

[27] F. Dieli, N. Gebbia, F. Poccia et al., "Induction of $\gamma \delta$ Tlymphocyte effector functions by bisphosphonate zoledronic acid in cancer patients in vivo," Blood, vol. 102, no. 6, pp. 2310-2311, 2003.

[28] J. Zhu and W. E. Paul, "Peripheral CD4+ T-cell differentiation regulated by networks of cytokines and transcription factors," Immunological Reviews, vol. 238, no. 1, pp. 247-262, 2010.

[29] J. Banchereau and R. M. Steinman, "Dendritic cells and the control of immunity," Nature, vol. 392, no. 6673, pp. 245252, 1998.

[30] L. M. Bradley, K. Yoshimoto, and S. L. Swain, "The cytokines IL-4, IFN- $\gamma$, and IL-12 regulate the development of subsets of memory effector helper $\mathrm{T}$ cells in vitro," Journal of Immunology, vol. 155, no. 4, pp. 1713-1724, 1995.

[31] C. Wiethe, A. Debus, M. Mohrs, A. Steinkasserer, M. Lutz, and A. Gessner, "Dendritic cell differentiation state and their interaction with NKT cells determine Th1/Th2 differentiation in the murine model of Leishmania major infection," Journal of Immunology, vol. 180, no. 7, pp. 4371-4381, 2008.

[32] C. Dong, "TH17 cells in development: an updated view of their molecular identity and genetic programming," Nature Reviews Immunology, vol. 8, no. 5, pp. 337-348, 2008. 
[33] G. Canderan and P. Dellabona, "T helper 17 T cells do good for cancer immunotherapy," Immunotherapy, vol. 2, no. 1, pp. 21-24, 2010.

[34] M. J. Cannon, H. Goyne, P. J.B. Stone, and M. ChirivaInternati, "Dendritic cell vaccination against ovarian cancertipping the Treg/T H17 balance to therapeutic advantage?" Expert Opinion on Biological Therapy, vol. 11, no. 4, pp. 441445, 2011.

[35] S. Koido, S. Homma, E. Hara et al., "In vitro generation of cytotoxic and regulatory $\mathrm{T}$ cells by fusions of human dendritic cells and hepatocellular carcinoma cells," Journal of Translational Medicine, vol. 6, article 51, 2008.

[36] Y. Oji, S. Nakamori, M. Fujikawa et al., "Overexpression of the Wilms' tumor gene WT1 in pancreatic ductal adenocarcinoma," Cancer Science, vol. 95, no. 7, pp. 583-587, 2004.

[37] M. Ueda, Y. Miura, O. Kunihiro et al., "MUC1 overexpression is the most reliable marker of invasive carcinoma in intraductal papillary-mucinous tumor (IPMT)," HepatoGastroenterology, vol. 52, no. 62, pp. 398-403, 2005.

[38] K. Seki, T. Suda, Y. Aoyagi et al., "Diagnosis of pancreatic adenocarcinoma by detection of human telomerase reverse transcriptase messenger RNA in pancreatic juice with sample qualification," Clinical Cancer Research, vol. 7, no. 7, pp. 1976-1981, 2001.

[39] M. K. Gjertsen, A. Bakka, J. Breivik et al., "Vaccination with mutant ras peptides and induction of T-cell responsiveness in pancreatic carcinoma patients carrying the corresponding RAS mutation," Lancet, vol. 346, no. 8987, pp. 1399-1400, 1995.

[40] M. Wobser, P. Keikavoussi, V. Kunzmann, M. Weininger, M. H. Andersen, and J. C. Becker, "Complete remission of liver metastasis of pancreatic cancer under vaccination with a HLA-A2 restricted peptide derived from the universal tumor antigen survivin," Cancer Immunology, Immunotherapy, vol. 55, no. 10, pp. 1294-1298, 2006.

[41] K. Yamaguchi, M. Enjoji, and M. Tsuneyoshi, "Pancreatoduodenal carcinoma: a clinicopathologic study of 304 patients and immunohistochemical observation for CEA and CA19-9," Journal of Surgical Oncology, vol. 47, no. 3, pp. 148$154,1991$.

[42] M. Komoto, B. Nakata, R. Amano et al., "HER2 overexpression correlates with survival after curative resection of pancreatic cancer," Cancer Science, vol. 100, no. 7, pp. 1243 1247, 2009.

[43] H. Maacke, A. Kessler, W. Schmiegel et al., "Overexpression of p53 protein during pancreatitis," British Journal of Cancer, vol. 75, no. 10, pp. 1501-1504, 1997.

[44] S. Koido, S. Homma, E. Hara et al., "Regulation of tumor immunity by tumor/dendritic cell fusions," Clinical and Developmental Immunology, vol. 2010, Article ID 516768, 2010.

[45] D. Mougiakakos, A. Choudhury, A. Lladser, R. Kiessling, and C. C. Johansson, "Regulatory T cells in cancer," Advances in cancer research, vol. 107, pp. 57-117, 2010.

[46] E. M. Shevach, "Mechanisms of foxp3+ T regulatory cellmediated suppression," Immunity, vol. 30, no. 5, pp. 636-645, 2009.

[47] A. W. Purcell, J. McCluskey, and J. Rossjohn, "More than one reason to rethink the use of peptides in vaccine design," Nature Reviews Drug Discovery, vol. 6, no. 5, pp. 404-414, 2007.

[48] M. S. Bijker, C. J. Melief, R. Offringa, and S. H. van der Burg, "Design and development of synthetic peptide vaccines: past, present and future," Expert Review of Vaccines, vol. 6, no. 4, pp. 591-603, 2007.

[49] H. Yanagimoto, T. Mine, K. Yamamoto et al., "Immunological evaluation of personalized peptide vaccination with gemcitabine for pancreatic cancer," Cancer Science, vol. 98, no. 4, pp. 605-611, 2007.

[50] M. Miyazawa, R. Ohsawa, T. Tsunoda et al., "Phase I clinical trial using peptide vaccine for human vascular endothelial growth factor receptor 2 in combination with gemcitabine for patients with advanced pancreatic cancer," Cancer Science, vol. 101, no. 2, pp. 433-439, 2010.

[51] S. Kanodia and W. M. Kast, "Peptide-based vaccines for cancer: realizing their potential," Expert Review of Vaccines, vol. 7, no. 10, pp. 1533-1545, 2008.

[52] C. J. Voskens, S. E. Strome, and D. A. Sewell, "Synthetic peptide-based cancer vaccines: lessons learned and hurdles to overcome," Current Molecular Medicine, vol. 9, no. 6, pp. 683-693, 2009.

[53] S. Mocellin, P. Pilati, and D. Nitti, "Peptide-based anticancer vaccines: recent advances and future perspectives," Current Medicinal Chemistry, vol. 16, no. 36, pp. 4779-4796, 2009.

[54] H. Yanagimoto, S. Takai, S. Satoi et al., "Impaired function of circulating dendritic cells in patients with pancreatic cancer," Clinical Immunology, vol. 114, no. 1, pp. 52-60, 2005.

[55] S. Koido, E. Hara, S. Homma et al., "Dendritic/pancreatic carcinoma fusions for clinical use: comparative functional analysis of healthy- versus patient-derived fusions," Clinical Immunology, vol. 135, no. 3, pp. 384-400, 2010.

[56] M. K. Gjertsen, T. Buanes, A. R. Rosseland et al., "Intradermal ras peptide vaccination with granulocyte-macrophage colony-stimulating factor as adjuvant: clinical and immunological responses in patients with pancreatic adenocarcinoma," International Journal of Cancer, vol. 92, no. 3, pp. 441-450, 2001.

[57] G. K. Abou-Alfa, P. B. Chapman, J. Feilchenfeldt et al., "Targeting mutated K-ras in pancreatic adenocarcinoma using an adjuvant vaccine," American Journal of Clinical Oncology, vol. 34, no. 3, pp. 321-325, 2011.

[58] K. Yamamoto, T. Ueno, T. Kawaoka et al., "MUC1 peptide vaccination in patients with advanced pancreas or biliary tract cancer," Anticancer Research, vol. 25, no. 5, pp. 35753579, 2005.

[59] R. K. Ramanathan, K. M. Lee, J. McKolanis et al., "Phase I study of a MUC1 vaccine composed of different doses of MUC1 peptide with SB-AS2 adjuvant in resected and locally advanced pancreatic cancer," Cancer Immunology, Immunotherapy, vol. 54, no. 3, pp. 254-264, 2005.

[60] S. L. Bernhardt, M. K. Gjertsen, S. Trachsel et al., "Telomerase peptide vaccination of patients with non-resectable pancreatic cancer: a dose escalating phase I/II study," British Journal of Cancer, vol. 95, no. 11, pp. 1474-1482, 2006.

[61] K. Itoh, A. Yamada, T. Mine, and M. Noguchi, "Recent advances in cancer vaccines: an overview," Japanese Journal of Clinical Oncology, vol. 39, no. 2, pp. 73-80, 2009.

[62] K. Yamamoto, T. Mine, K. Katagiri et al., "Immunological evaluation of personalized peptide vaccination for patients with pancreatic cancer," Oncology Reports, vol. 13, no. 5, pp. 874-883, 2005.

[63] C. J. M. Melief and S. H. van der Burg, "Immunotherapy of established (pre)malignant disease by synthetic long peptide vaccines," Nature Reviews Cancer, vol. 8, no. 5, pp. 351-360, 2008.

[64] M. S. Bijker, S. J. F. van den Eeden, K. L. Franken, C. J. M. Melief, S. H. van der Burg, and R. Offringa, "Superior induction 
of anti-tumor CTL immunity by extended peptide vaccines involves prolonged, DC-focused antigen presentation," European Journal of Immunology, vol. 38, no. 4, pp. 1033-1042, 2008.

[65] S. Wedén, M. Klemp, I. P. Gladhaug et al., "Long-term followup of patients with resected pancreatic cancer following vaccination against mutant K-ras," International Journal of Cancer, vol. 128, no. 5, pp. 1120-1128, 2011.

[66] S. Koido, E. Hara, S. Homma et al., "Dendritic cells fused with allogeneic colorectal cancer cell line present multiple colorectal cancer-specific antigens and induce antitumor immunity against autologous tumor cells," Clinical Cancer Research, vol. 11, no. 21, pp. 7891-7900, 2005.

[67] E. M. Jaffee, R. H. Hruban, B. Biedrzycki et al., "Novel allogeneic granulocyte-macrophagecolony-stimulating factorsecreting tumor vaccine for pancreatic cancer: a phase I trial of safety and immune activation," Journal of Clinical Oncology, vol. 19, no. 1, pp. 145-156, 2001.

[68] D. Laheru, B. Biedrzycki, and E. M. Jaffee, "Immunologic approaches to the management of pancreatic cancer," Cancer Journal, vol. 7, no. 4, pp. 324-337, 2001.

[69] K. M. Hege, K. Jooss, and D. Pardoll, "GM-CSF genemodifed cancer cell immunotherapies: of mice and men," International Reviews of Immunology, vol. 25, no. 5-6, pp. 321-352, 2006.

[70] D. Laheru, E. Lutz, J. Burke et al., "Allogeneic granulocyte macrophage colony-stimulating factor-secreting tumor immunotherapy alone or in sequence with cyclophosphamide for metastatic pancreatic cancer: a pilot study of safety, feasibility, and immune activation," Clinical Cancer Research, vol. 14 , no. 5 , pp. 1455-1463, 2008.

[71] R. Förster, A. Schubel, D. Breitfeld et al., "CCR7 coordinates the primary immune response by establishing functional microenvironments in secondary lymphoid organs," Cell, vol. 99, no. 1, pp. 23-33, 1999.

[72] J. Banchereau and A. K. Palucka, "Dendritic cells as therapeutic vaccines against cancer," Nature Reviews Immunology, vol. 5, no. 4, pp. 296-306, 2005.

[73] F. O. Nestle, S. Alijagic, M. Gilliet et al., "Vaccination of melanoma patients with peptide- or tumor lysate-pulsed dendritic cells," Nature Medicine, vol. 4, no. 3, pp. 328-332, 1998.

[74] A. Mackensen, B. Herbst, J. L. Chen et al., "Phase I study in melanoma patients of a vaccine with peptide-pulsed dendritic cells generated in vitro from CD34+ hematopoietic progenitor cells," International Journal of Cancer, vol. 89, no. 2, pp. 385-392, 2000.

[75] A. K. Palucka, H. Ueno, J. Connolly et al., "Dendritic cells loaded with killed allogeneic melanoma cells can induce objective clinical responses and MART-1 specific CD8+ Tcell immunity," Journal of Immunotherapy, vol. 29, no. 5, pp. 545-557, 2006.

[76] S. K. Nair, D. Boczkowski, M. Morse, R. I. Cumming, H. K. Lyerly, and E. Gilboa, "Induction of primary carcinoembryonic antigen (CEA)-specific cytotoxic T lymphocytes in vitro using human dendritic cells transfected with RNA," Nature Biotechnology, vol. 16, no. 4, pp. 364-369, 1998.

[77] W. W. Leitner, H. Ying, and N. P. Restifo, "DNA and RNAbased vaccines: principles, progress and prospects," Vaccine, vol. 18, no. 9-10, pp. 765-777, 1999.

[78] E. Gilboa and J. Vieweg, "Cancer immunotherapy with mRNA-transfected dendritic cells," Immunological Reviews, vol. 199, pp. 251-263, 2004.

[79] J. Gong, D. Chen, M. Kashiwaba, and D. Kufe, "Induction of antitumor activity by immunization with fusions of dendritic and carcinoma cells," Nature Medicine, vol. 3, no. 5, pp. 558$561,1997$.

[80] S. Koido, E. Hara, S. Homma, K. Fujise, J. Gong, and H. Tajiri, "Dendritic/tumor fusion cell-based vaccination against cancer," Archivum Immunologiae et Therapiae Experimentalis, vol. 55, no. 5, pp. 281-287, 2007.

[81] J. Gong, S. Koido, and S. K. Calderwood, "Cell fusion: from hybridoma to dendritic cell-based vaccine," Expert Review of Vaccines, vol. 7, no. 7, pp. 1055-1068, 2008.

[82] S. Koido, E. Hara, S. Homma, T. Ohkusa, J. Gong, and H. Tajiri, "Cancer immunotherapy by fusions of dendritic cells and tumor cells," Immunotherapy, vol. 1, no. 1, pp. 49-62, 2009.

[83] D. Avigan, B. Vasir, J. Gong et al., "Fusion cell vaccination of patients with metastatic breast and renal cancer induces immunological and clinical responses," Clinical Cancer Research, vol. 10, no. 14, pp. 4699-4708, 2004.

[84] T. Kikuchi, Y. Akasaki, T. Abe et al., "Vaccination of glioma patients with fusions of dendritic and glioma cells and recombinant human interleukin 12," Journal of Immunotherapy, vol. 27, no. 6, pp. 452-459, 2004.

[85] S. Homma, T. Kikuchi, N. Ishiji et al., "Cancer immunotherapy by fusions of dendritic and tumour cells and rh-IL-12," European Journal of Clinical Investigation, vol. 35, no. 4, pp. 279-286, 2005.

[86] S. Homma, Y. Sagawa, M. Ito, T. Ohno, and G. Toda, "Cancer immunotherapy using dendritic/tumour-fusion vaccine induces elevation of serum anti-nuclear antibody with better clinical responses," Clinical and Experimental Immunology, vol. 144, no. 1, pp. 41-47, 2006.

[87] C. K. Tang, M. Katsara, and V. Apostolopoulos, "Strategies used for MUC1 immunotherapy: human clinical studies," Expert Review of Vaccines, vol. 7, no. 7, pp. 963-975, 2008.

[88] A. J. Lepisto, A. J. Moser, H. Zeh et al., "A phase I/II study of a MUC1 peptide pulsed autologous dendritic cell vaccine as adjuvant therapy in patients with resected pancreatic and biliary tumors," Cancer Therapy, vol. 6, no. B, pp. 955-964, 2008.

[89] G. Pecher, A. Häring, L. Kaiser, and E. Thiel, "Mucin gene (MUC1) transfected dendritic cells as vaccine: results of a phase I/II clinical trial," Cancer Immunology, Immunotherapy, vol. 51, no. 11-12, pp. 669-673, 2002.

[90] G. L. Beatty and R. H. Vonderheide, "Telomerase as a universal tumor antigen for cancer vaccines," Expert Review of Vaccines, vol. 7, no. 7, pp. 881-887, 2008.

[91] S. Sæbøe-Larssen, E. Fossberg, and G. Gaudernack, "mRNAbased electrotransfection of human dendritic cells and induction of cytotoxic T lymphocyte responses against the telomerase catalytic subunit (hTERT)," Journal of Immunological Methods, vol. 259, no. 1-2, pp. 191-203, 2002.

[92] P. F. Brunsvig, S. Aamdal, M. K. Gjertsen et al., "Telomerase peptide vaccination: a phase I/II study in patients with nonsmall cell lung cancer," Cancer Immunology, Immunotherapy, vol. 55, no. 12, pp. 1553-1564, 2006.

[93] E. M.I. Suso, S. Dueland, A. -M. Rasmussen et al., "hTERT mRNA dendritic cell vaccination: complete response in a pancreatic cancer patient associated with response against several hTERT epitopes," Cancer Immunology, Immunotherapy, pp. 1-10, 2011.

[94] Y. Kimura, K. Imai, K. Shimamura et al., "Clinical and immunologic evaluation of dendriticcell-based immunotherapy in combination with gemcitabine and/or S-1 in the patients with advanced pancreatic carcinoma," Pancreas. In press. 
[95] G. Eschenburg, A. Stermann, R. Preissner, H. -A. Meyer, and H. N. Lode, "DNA vaccination: using the patient's immune system to overcome cancer," Clinical and Developmental Immunology, vol. 2010, Article ID 169484, 2010.

[96] Y. Rong, D. Jin, W. Wu et al., "Induction of protective and therapeutic anti-pancreatic cancer immunity using a reconstructed MUC1 DNA vaccine," BMC Cancer, vol. 9, article 191, 2009.

[97] K. Zhu, H. Qin, S. C. Cha et al., "Survivin DNA vaccine generated specific antitumor effects in pancreatic carcinoma and lymphoma mouse models," Vaccine, vol. 25, no. 46, pp. 7955-7961, 2007.

[98] D. I. Gabrilovich, "Combination of chemotherapy and immunotherapy for cancer: a paradigm revisited," Lancet Onco$\log y$, vol. 8, no. 1, pp. 2-3, 2007.

[99] B. D. Smith, Y. L. Kasamon, J. Kowalski et al., "K562/GMCSF immunotherapy reduces tumor burden in chronic myeloid leukemia patients with residual disease on imatinib mesylate," Clinical Cancer Research, vol. 16, no. 1, pp. 338347, 2010.

[100] J. M. Plate, A. E. Plate, S. Shott, S. Bograd, and J. E. Harris, "Effect of gemcitabine on immune cells in subjects with adenocarcinoma of the pancreas," Cancer Immunology, Immunotherapy, vol. 54, no. 9, pp. 915-925, 2005.

[101] J. M. Hou, J. Y. Liu, L. Yang et al., "Combination of lowdose gemcitabine and recombinant quail vascular endothelial growth factor receptor-2 as a vaccine induces synergistic antitumor activities," Oncology, vol. 69, no. 1, pp. 81-87, 2005.

[102] A. Soeda, Y. Morita-Hoshi, H. Makiyama et al., "Regular dose of gemcitabine induces an increase in CD14+ monocytes and $\mathrm{CD} 11 \mathrm{c}+$ dendritic cells in patients with advanced pancreatic cancer," Japanese Journal of Clinical Oncology, vol. 39, no. 12, pp. 797-806, 2009.

[103] P. Correale, M. G. Cusi, M. T. Del Vecchio et al., "Dendritic cell-mediated cross-presentation of antigens derived from colon carcinoma cells exposed to a highly cytotoxic multidrug regimen with gemcitabine, oxaliplatin, 5-fluorouracil, and leucovorin, elicits a powerful human antigen-specific CTL response with antitumor activity in vitro," Journal of Immunology, vol. 175, no. 2, pp. 820-828, 2005.

[104] A. K. Nowak, R. A. Lake, A. L. Marzo et al., "Induction of tumor cell apoptosis in vivo increases tumor antigen crosspresentation, cross-priming rather than cross-tolerizing host tumor-specific CD8 T cells," Journal of Immunology, vol. 170, no. 10, pp. 4905-4913, 2003.

[105] A. K. Nowak, B. W. S. Robinson, and R. A. Lake, "Synergy between chemotherapy and immunotherapy in the treatment of established murine solid tumors," Cancer Research, vol. 63, no. 15, pp. 4490-4496, 2003.

[106] M. Dauer, J. Herten, C. Bauer et al., "Chemosensitization of pancreatic carcinoma cells to enhance $\mathrm{T}$ cell-mediated cytotoxicity induced by tumor lysate-pulsed dendritic cells," Journal of Immunotherapy, vol. 28, no. 4, pp. 332-342, 2005.

[107] E. Suzuki, V. Kapoor, A. S. Jassar, L. R. Kaiser, and S. M. Albelda, "Gemcitabine selectively eliminates splenic Gr$1+/ \mathrm{CD} 11 \mathrm{~b}+$ myeloid suppressor cells in tumor-bearing animals and enhances antitumor immune activity," Clinical Cancer Research, vol. 11, no. 18, pp. 6713-6721, 2005.

[108] S. Nagaraj, J. I. Youn, H. Weber et al., "Anti-inflammatory triterpenoid blocks immune suppressive function of MDSCs and improves immune response in cancer," Clinical Cancer Research, vol. 16, no. 6, pp. 1812-1823, 2010.
[109] C. Bauer, F. Bauernfeind, A. Sterzik et al., "Dendritic cellbased vaccination combined with gemcitabine increases survival in a murine pancreatic carcinoma model," Gut, vol. 56, no. 9, pp. 1275-1282, 2007.

[110] R. Ramakrishnan, D. Assudani, S. Nagaraj et al., "Chemotherapy enhances tumor cell susceptibility to CTL-mediated killing during cancer immunotherapy in mice," Journal of Clinical Investigation, vol. 120, no. 4, pp. 1111-1124, 2010.

[111] D. Weng, B. Song, J. Durfee et al., "Induction of cytotoxic T lymphocytes against ovarian cancer-initiating cells," International Journal of Cancer, vol. 129, no. 8, pp. 1990-2001, 2011.

[112] Z. Wang, Y. Li, A. Ahmad et al., "Pancreatic cancer: understanding and overcoming chemoresistance," Nature Reviews Gastroenterology and Hepatology, vol. 8, no. 1, pp. 27-33, 2011.

[113] M. Dean, T. Fojo, and S. Bates, "Tumour stem cells and drug resistance," Nature Reviews Cancer, vol. 5, no. 4, pp. 275-284, 2005.

[114] Z. Du, R. Qin, C. Wei et al., "Pancreatic cancer cells resistant to chemoradiotherapy rich in "stem-cell-like" tumor cells," Digestive Diseases and Sciences, vol. 56, no. 3, pp. 741-750, 2010.

[115] C. Li, D. G. Heidt, P. Dalerba et al., "Identification of pancreatic cancer stem cells," Cancer Research, vol. 67, no. 3, pp. 1030-1037, 2007.

[116] C. J. Lee, J. Dosch, and D. M. Simeone, "Pancreatic cancer stem cells," Journal of Clinical Oncology, vol. 26, no. 17, pp. 2806-2812, 2008.

[117] Y. H. Wang, F. Li, B. Luo et al., "A side population of cells from a human pancreatic carcinoma cell line harbors cancer stem cell characteristics," Neoplasma, vol. 56, no. 5, pp. 371378, 2009.

[118] S. -N. Zhang, F. -T. Huang, Y. -J. Huang, W. Zhong, and Z. $\mathrm{Yu}$, "Characterization of a cancer stem cell-like side population derived from human pancreatic adenocarcinoma cells," Tumori, vol. 96, no. 6, pp. 985-992, 2010.

[119] P. H. Sung, J. Wen, S. Bang, S. Park, and Y. S. Si, "CD44positive cells are responsible for gemcitabine resistance in pancreatic cancer cells," International Journal of Cancer, vol. 125, no. 10, pp. 2323-2331, 2009.

[120] S. Inoda, Y. Hirohashi, T. Torigoe et al., "Cytotoxic T lymphocytes efficiently recognize human colon cancer stem-like cells," American Journal of Pathology, vol. 178, no. 4, pp. 1805-1813, 2011.

[121] Y. Hirohashi, T. Torigoe, S. Inoda et al., "Immune response against tumor antigens expressed on human cancer stem-like cells/tumor-initiating cells," Immunotherapy, vol. 2, no. 2, pp. 201-211, 2010.

[122] K. Engelmann, H. Shen, and O. J. Finn, "MCF7 side population cells with characteristics of cancer stem/progenitor cells express the tumor antigen MUC1," Cancer Research, vol. 68, no. 7, pp. 2419-2426, 2008.

[123] M. A. Cheever, J. P. Allison, A. S. Ferris et al., "The prioritization of cancer antigens: a National Cancer Institute pilot project for the acceleration of translational research," Clinical Cancer Research, vol. 15, no. 17, pp. 5323-5337, 2009.

[124] H. Sugiyama, "WT1 (Wilms' tumor gene 1): biology and cancer immunotherapy," Japanese Journal of Clinical Oncology, vol. 40, no. 5, pp. 377-387, 2010.

[125] P. Correale, A. Aquino, A. Giuliani et al., "Treatment of colon and breast carcinoma cells with 5-fluorouracil enhances expression of carcinoembryonic antigen and susceptibility to HLA-A $*$ * 02.01 restricted, CEA-peptide-specific Cytotoxic 
T cells in vitro," International Journal of Cancer, vol. 104, no. 4, pp. 437-445, 2003.

[126] P. Correale, M. T. Del Vecchio, M. La Placa et al., "Chemotherapeutic drugs may be used to enhance the killing efficacy of human tumor antigen peptide-specific CTLs," Journal of Immunotherapy, vol. 31, no. 2, pp. 132-147, 2008.

[127] R. Ramakrishnan and D. I. Gabrilovich, "Mechanism of synergistic effect of chemotherapy and immunotherapy of cancer," Cancer Immunology, Immunotherapy, vol. 60, no. 3, pp. 419-423, 2011.

[128] H. Yanagimoto, H. Shiomi, S. Satoi et al., "A phase II study of personalized peptide vaccination combined with gemcitabine for non-resectable pancreatic cancer patients," Oncology Reports, vol. 24, no. 3, pp. 795-801, 2010.

[129] Y. Hirooka, A. Itoh, H. Kawashima et al., "A combination therapy of gemcitabine with immunotherapy for patients with inoperable locally advanced pancreatic cancer," Pancreas, vol. 38, no. 3, pp. e69-e74, 2009.

[130] Y. Oka, A. Tsuboi, T. Taguchi et al., "Induction of WT1 (Wilms' tumor gene)-specific cytotoxic T lymphocytes by WT1 peptide vaccine and the resultant cancer regression," Proceedings of the National Academy of Sciences of the United States of America, vol. 101, no. 38, pp. 13885-13890, 2004.

[131] A. Takahara, S. Koido, M. Ito et al., "Gemcitabine enhances Wilms' tumor gene WT1 expression and sensitizes human pancreatic cancer cells with WT1-specific T-cell-mediated antitumor immune response," Cancer Immunology, Immunotherapy, vol. 60, no. 9, pp. 1289-1297, 2011. 


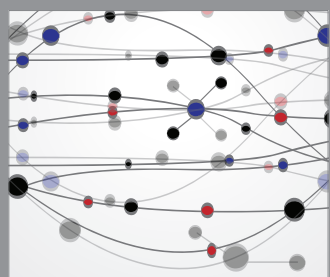

The Scientific World Journal
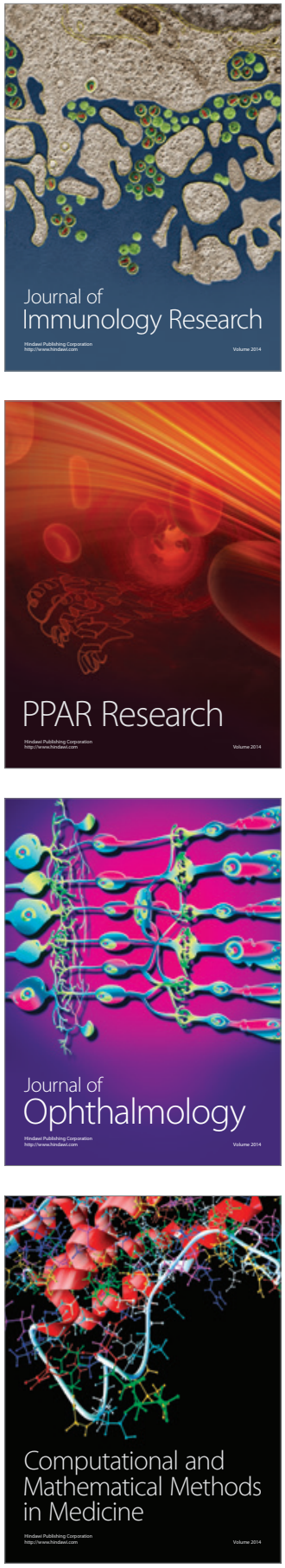

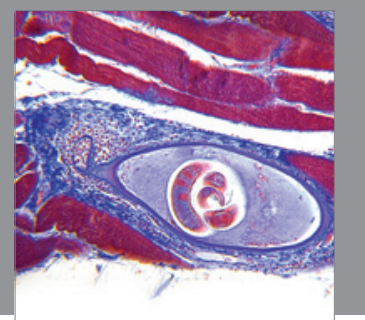

Gastroenterology

Research and Practice
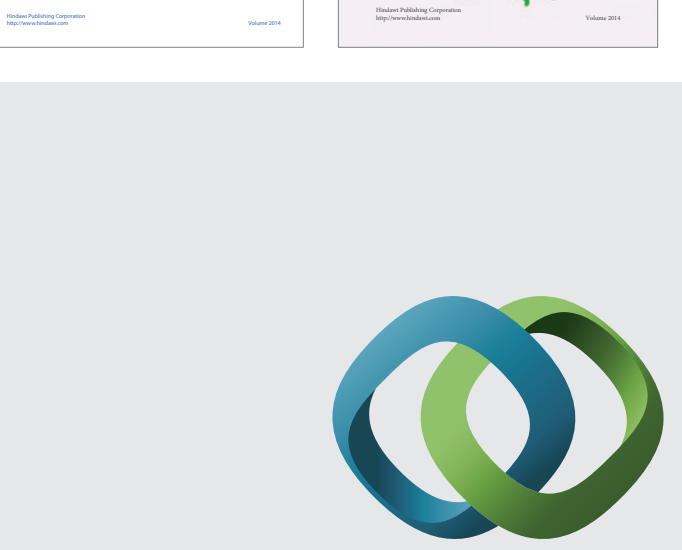

\section{Hindawi}

Submit your manuscripts at

http://www.hindawi.com
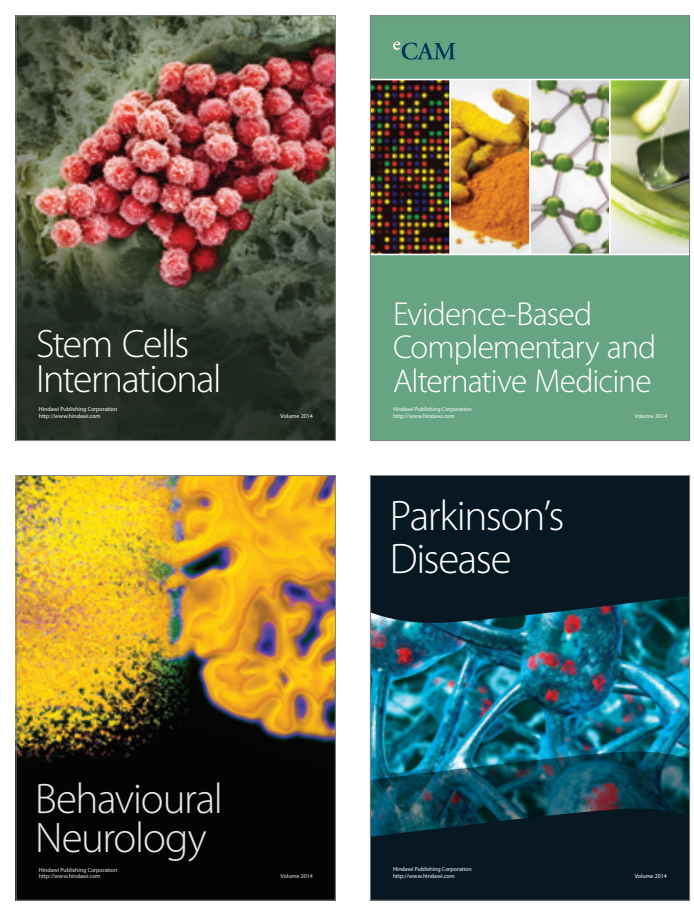

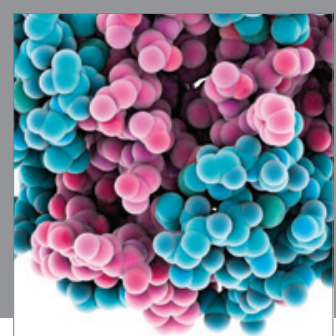

Journal of
Diabetes Research

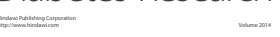

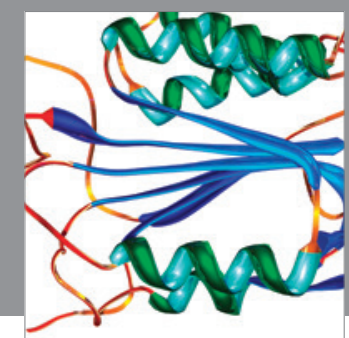

Disease Markers
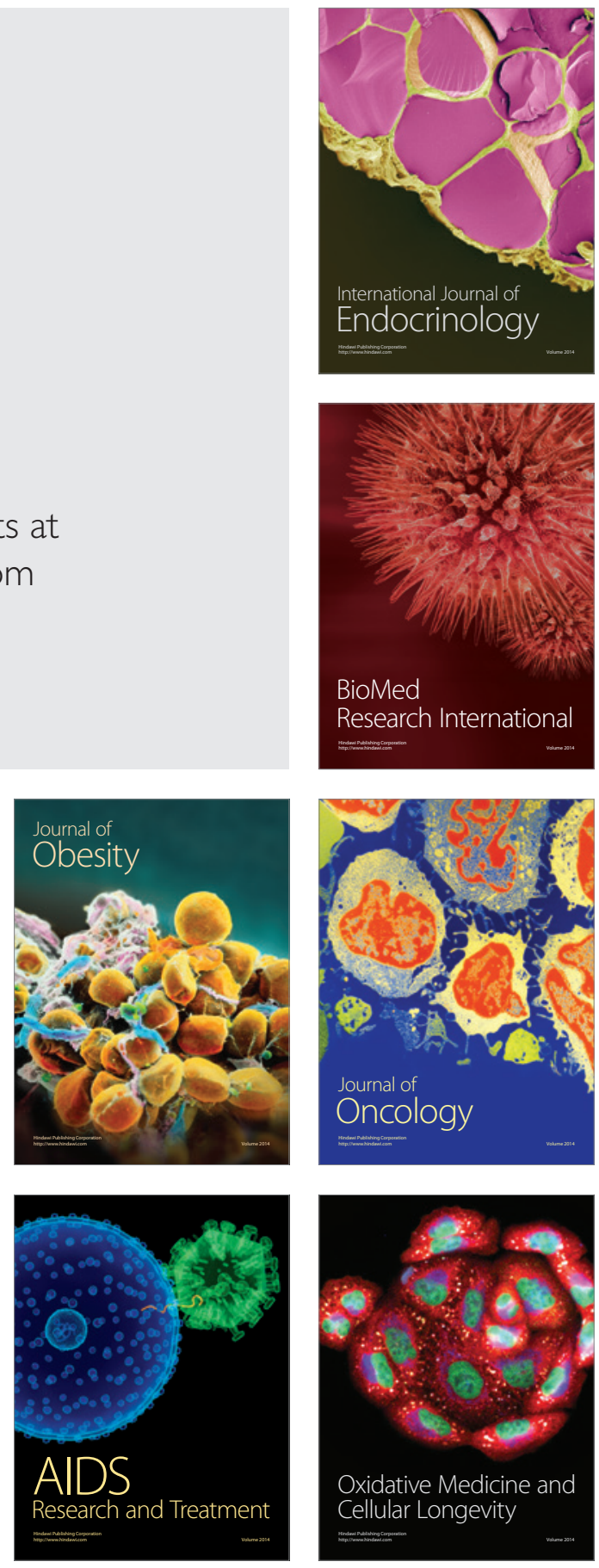